\title{
Morphological, Biochemical and Molecular Characterization of Twelve Nitrogen-Fixing Bacteria and Their Response to Various Zinc Concentration
}

\author{
Mohammad Dadook ${ }^{1}$; Sedigheh Mehrabian ${ }^{1}$; Mitra Salehi ${ }^{1}$; Saeed Irian ${ }^{2,}$ \\ ${ }^{1}$ Faculty of Biological Science, Islamic Azad University Tehran North Branch, Tehran, IR Iran \\ ${ }^{2}$ Department of Cell and Molecular Biology, Faculty of Biological Sciences, Kharazmi University, Tehran, IR Iran \\ ${ }^{*}$ Corresponding author: Saeed Irian, Department of Cell and Molecular Biology, Faculty of Biological Sciences, Kharazmi University, Tehran, IR Iran. Tel: +98-2188329220, E-mail: \\ irian@khu.ac.ir
}

Received: December 2, 2012; Revised: April 25, 2013; Accepted: May 8, 2013

\begin{abstract}
Background: Zinc is an essential micronutrient used in the form of zinc sulfate in fertilizers in the agriculture production system. Nitrogen-fixing microorganisms are also of considerable value in promoting soil fertility.

Objectives: This study aimed to investigate the degree of sensitivity to varying concentrations of zinc, in the form of $\mathrm{ZnSO} 4$, in different strains of Azotobacter chroococcum in a laboratory environment.

Materials and Methods: To isolate A. chroococcum strains, soil samples were collected from wheat, corn and asparagus rhizospheres and cultured in media lacking nitrogen at $30^{\circ} \mathrm{C}$ for 48 hours. Strains were identified based on morphological and biochemical characteristics. The presence of the nitrogenase enzyme system was confirmed by testing for the presence of the nifH gene using PCR analysis. The minimum inhibitory concentration (MIC) and optimal zinc concentration for the growth of each strain was determined.

Results: A total of 12 bacterial strains were isolated from six different soil samples. A. chroococcum strains were morphologically and biochemically characterized. The presence of the nifH gene was confirmed in all the strains. MIC and the optimal zinc concentration for bacterial growth were $50 \mathrm{ppm}$ and $20 \mathrm{ppm}$, respectively.

Conclusions: It was concluded that increasing the concentration of zinc in the agricultural soil is harmful to beneficial microorganisms and reduces the soil fertility. A20-ppm zinc concentration in soil is suggested to be optimal.
\end{abstract}

Keywords:Zinc; Azotobacter; nifH Gene

\section{Background}

Heavy metals are elements with an atomic mass greater than $40 \mathrm{~g}$ and a specific weight of more than $5 \mathrm{~g} / \mathrm{cm}^{3}$ (1). These elements often find their way into soil through environmental contaminants including the atmospheric pollutants in the industrial regions, unlimited use of agricultural fertilizers, and municipal and industrial sewage system in a nonreturnable fashion (2). Unlike organic contaminants which can be converted to nontoxic compounds, metals are intrinsically stable in nature (3). Certain metals including zinc ( $\mathrm{Zn}$ ) are essential for plant growth and development, when used as a micronutrient, however, when used in greater amounts, may result in metabolic disorders, eventually suppress the growth of most plants and microorganisms (4). Generating free radicals and oxidative stress are important mechanisms that heavy metals, including zinc apply to induce toxicity (5).

In general, variation and distribution of microorganisms is a reflection of soil fertility. As nitrogen is an essen- tial element for plants, nitrogen-fixing bacteria would provide molecular nitrogen for plant use (6). Azotobacter species belong to the Gram-negative and the polymorphic family of Azotobacteraceae are capable to forming capsule and microcyst (7). By fixing nitrogen and producing thiamin, riboflavin, nicotin, indole-3-acetic acid (IAA) and gibberellin, these bacteria participate in plant cell growth (8). Molecular nitrogen is converted to ammonia by the nitrogenase in the biological nitrogen fixation process. Synthesis of a functional nitrogenase requires the expression of nif genes. The structural gene nifH, as an important nif gene, is involved in the formation of Feprotein complex (9). Nitrogen-fixing bacteria can now be detected based on the presence of nif gene using PCR or sequencing techniques (10).

\section{Objectives}

Due to the key role played by the nitrogen-fixing microorganisms in the agricultural soil, and the importance of the metal zinc as an essential micronutrient in biological 
cycles along with its toxic effect on the environment, this study aimed at investigating the degree of sensitivity to different concentrations of zinc, in the form of $\mathrm{ZnSO}_{4}$, in different strains of Azotobacter chroococcum in a laboratory environment.

\section{Materials and Methods}

All chemicals and reagents were purchased from Merck (Germany).

\subsection{Soil Sampling}

Soil samples were collected during April 2012 in Aznova Behnamir, Mazandaran province, Iran. Samples were withdrawn from $0-30 \mathrm{~cm}$ - depth surfaces, collected into sterile vials and transferred to laboratory. These included 1, 2 and 3 samples collected from wheat, corn and asparagus rhizospheres, respectively.

\subsection{Isolation of Nitrogen-Fixing Microorganisms From Agricultural Soil}

Isolation of A. chroococcum strains was performed in duplicates by the dilution-pour plates method $\left(10^{-1}-10^{-10}\right)$ on mannitol N-free agar medium containing: mannitol $10 \mathrm{~g}$, $\mathrm{K}_{2} \mathrm{HPO}_{4} 0.75 \mathrm{~g}, \mathrm{MgSO}_{4} 0.5 \mathrm{~g}, \mathrm{CaCO}_{3} 3 \mathrm{~g}$, sodium molybdate $0.02 \mathrm{~g}$, agar $18 \mathrm{~g}$ and $\mathrm{H}_{2} \mathrm{O}$ dist. $1000 \mathrm{~mL}$. Samples were incubated for 48 hours at $30^{\circ} \mathrm{C}$, before being subjected to both microscopic and macroscopic analysis. Bacterial cultures were repeated three times for a better isolation and purification purpose. Identification of the strains was performed using the routine microbiological method including biochemical tests $(11,12)$.

\subsection{Culture Inoculation}

Isolated colonies were grown on Brain Heart Infusion (BHI) agar plates at $30^{\circ} \mathrm{C}$ for 24 hours. Bacterial colonies were then inoculated into sterile physiological serum and the optical density (OD) was adjusted to 0.8-1 at 600 $\mathrm{nm}$, equivalent to $5 \times 10^{-8} \mathrm{CFU} / \mathrm{mL}$.

\subsection{Sensitivity Assay to Different Concentrations of Zinc Sulfate for Isolated Strains}

To assay the sensitivity of the isolated strains to zinc sulfate, samples of 0.1-10 mM serial concentrations of $\mathrm{ZnSO}_{4}{ }^{\circ} 7 \mathrm{H}_{2} \mathrm{O}$ [287.34 MW] were prepared in Luria Broth (LB) medium and sterilized. Then $1 \mathrm{~mL}$ of the bacterial sample was added to each medium and incubated at $30^{\circ} \mathrm{C}$ for 24 hours on a shaking incubator prior to measuring the OD at $600 \mathrm{~nm}$. In a different approach, the sensitivity level was determined in $100 \mathrm{~mL}$ of LB containing 10 to $100 \mathrm{ppm}$ of zinc sulfate and $1 \%(\mathrm{v} / \mathrm{v})$ bacterial inoculum in $300 \mathrm{~mL}$ flasks. These cultures were then incubated at $30^{\circ} \mathrm{C}$ for 24,48 and 72 hours on a shaking incubator, set at $125 \mathrm{rpm}$, prior to OD reading at $600 \mathrm{~nm}$. Positive (zincfree medium containing bacteria) and negative (minimum zinc concentration with no bacteria) controls were also included.

\subsection{The Presence of nifH Gene}

\subsubsection{Bacterial DNA Extraction}

Isolated bacteria were cultured in LB medium on a shaking incubator at $30^{\circ} \mathrm{C}$ for 18 hours. These cultures were then centrifuged at 12000 rpm for 2 minutes. Genomic DNA was extracted using the MBST DNA Extraction kit (Germany/Iran).

\subsubsection{Polymerase Chain Reaction}

A $25-\mu \mathrm{L}$ PCR reaction mix was prepared using primers: 5' TTCCATCAGCAGCTCTTCGA3' and 5' GGCAAAGGTGGTATCGGTAA3 ${ }^{-}$(Robin Teb Gostar-Iran). The PCR thermo cycling condition was $95^{\circ} \mathrm{C}$ for 3 minutes (preheating), $95^{\circ} \mathrm{C}$ for 30 seconds, $57^{\circ} \mathrm{C}$ for 30 seconds, and $72^{\circ} \mathrm{C}$ for 45 seconds and 30 cycles, followed by a final heating at $72^{\circ} \mathrm{C}$ for 7 minutes. The PCR product size was confirmed by electrophoresis on a $1 \%$ agarose gel (Bio-Rad-USA). All reagents, Taq polymerase and DNA ladder were purchased from Metabion (Germany).

\section{Results}

A total of $12 \mathrm{~A}$. chroococcum strains were identified in the agricultural soil samples collected from the rhizosphere. Microscopic and macroscopic examinations of the Gramnegative bacilli, capable to form cyst, white, transparent, viscous and moist colonies which turn dark brown after 5-7 days of incubation on a mannitol N-free agar medium, along with the biochemical tests revealed the identity of different A. chroococcum strains (Figure 1 and Table 1). The first method determined the MIC of all the strains as 0.8 mmol zinc sulfate (52.33 ppm), while the optimal growth rates of bacteria determined by OD analysis were 0.1, 0.2 and $0.3 \mathrm{mmol}$, equivalent to $6.53,13$ and $19.62 \mathrm{ppm}$, respectively (Figure 2).

In the second method no growth was detected at $40 \mathrm{ppm}$ after 24 hours, and the optimal growth of bacteria was observed at zinc concentrations of 10 and 20 ppm. In 48 and 72 hours the MIC was 50 ppm, while the optimal growth rate of bacteria was observed at 10 and 20 ppm. In addition, the bacteria examined in three different times had a similar growth pattern, and the highest degree of sensitivity of the strains appeared in the first 24 hours (Figure 3). The detection of nifH gene in DNA extracted from all $A$. chroococcum strains is indicative of the presence of the nitrogenase system in these bacteria (Figure 4). 
Figure 1. Microscopic (Light Microscope 100x) and Macroscopic Examinations of the Gram-Negative Bacilli, Capable of Forming Cyst
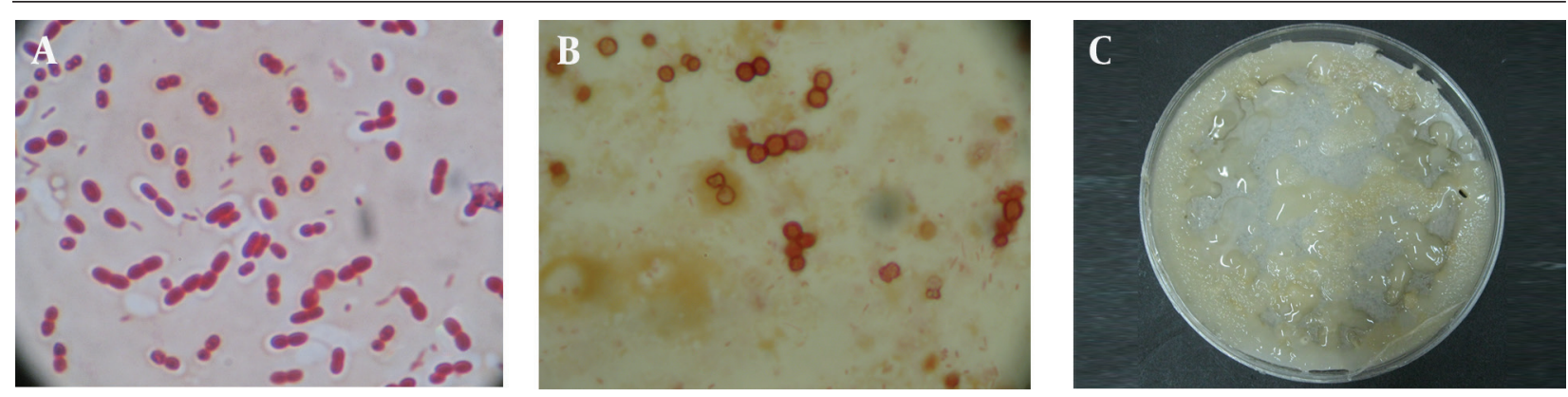

A. Gram-negative Bacilli; B. Cyst on Mannitol N-free Agar Medium; C. Colonies of A. chroococcum on Mannitol N-free Agar Medium

Table 1. A. chroococcum Identification Tests ${ }^{\text {a }}$

\begin{tabular}{|c|c|c|c|c|c|c|c|c|c|c|c|c|c|c|c|}
\hline Bacterial Strains & Cat & $\mathbf{O x}$ & Man F & Cys F & $\mathrm{N}_{2}$ Mic & St F & Nit R & Glu F & Sac F & In F & BC Fo & Mov & Capy F & Capr F & Rh F \\
\hline NFM1 & + & + & + & + & - & - & + & + & + & - & + & + & - & + & - \\
\hline NFM2 & + & + & + & + & - & - & + & + & + & - & + & + & - & + & - \\
\hline NFM3 & + & + & + & + & - & - & + & + & + & - & + & + & - & + & - \\
\hline NFM4 & + & + & + & + & - & - & + & + & + & - & + & + & - & + & - \\
\hline NFM5 & + & + & + & + & - & - & + & + & + & - & + & + & - & + & - \\
\hline NFM6 & + & + & + & + & - & - & + & + & + & - & + & + & - & + & - \\
\hline NFM7 & + & + & + & + & - & - & + & + & + & - & + & + & - & + & - \\
\hline NFM8 & + & + & + & + & - & - & + & + & + & - & + & + & - & + & - \\
\hline NFM9 & + & + & + & + & - & - & + & + & + & - & + & + & - & + & - \\
\hline NFM10 & + & + & + & + & - & - & + & + & + & - & + & + & - & + & - \\
\hline NFM11 & + & + & + & + & - & - & + & + & + & - & + & + & - & + & - \\
\hline NFM12 & + & + & + & + & - & - & + & + & + & - & + & + & - & + & - \\
\hline
\end{tabular}

a Abbreviations: B C Fo, brown colony formation; Mov, movement; Cap F, caproate fermentation; Capy F, caprylate fermentation; Cat, catalase; Cys F, cyst formation; Glu F, glucose fermentation; In F, innositol fermentation; Man F, manitol fermentation; $\mathrm{N}_{2}$ Mic, nitrogen fixation in a microaerophil condition; Ox, oxidase; Rh F, rhamnose fermentation; Sac F, saccharose fermentation; St F, starch fermentation; Nit R, nitrate reduction.

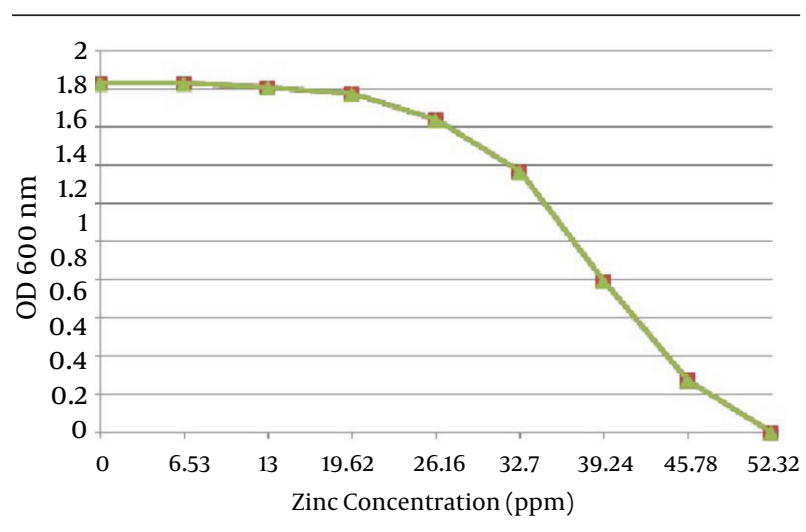

Figure 2. The Mean Optimal Growth Rate of Twelve A. chroococcum Strains at Different Concentrations of Zinc

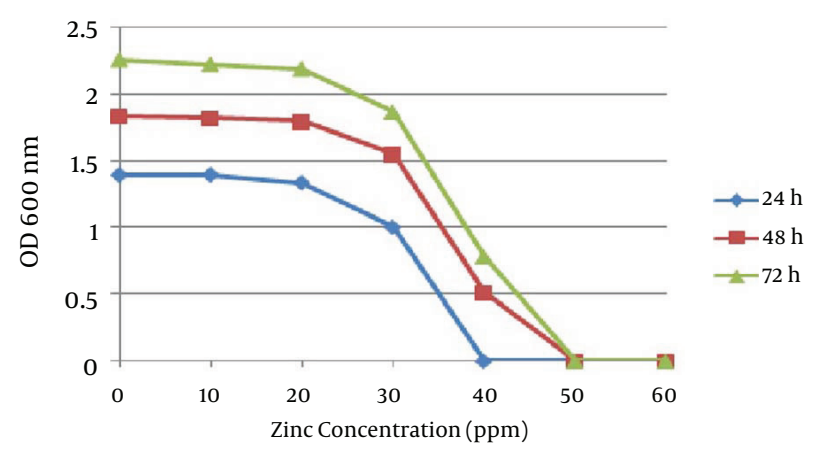

Figure 3. The Mean Optimal Growth Rate of Twelve A. chroococcum Strains at Different Concentrations of Zinc After 24, 48 and 72 Hours 


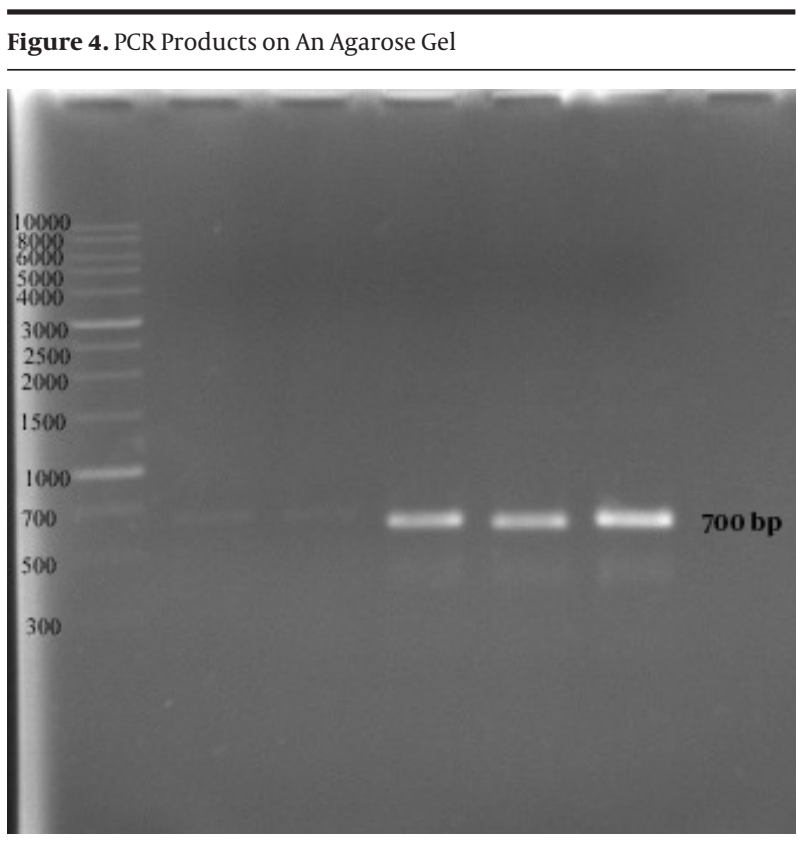

Image Showing the Presence of nifH Gene in DNA Extracted From Five A chroococcum Strains

\section{Discussion}

In this study, in addition to the isolation and identification of nitrogen-fixing soil-borne bacteria, the zincsensitivity of the different strains as well as the presence of nifH gene in the isolated strains were investigated. Of a total of 12 isolated $A$. chroococcum strains, all samples were capable to grow on a zinc-free medium as well as media containing a zinc concentration of $6-40 \mathrm{ppm}$, but not media with a zinc concentration of $50 \mathrm{ppm}$. These results are in line with those of Chengqun and Huang who used a nitrogen-free medium supplied with manitol, as a carbon source, to isolate Azotobacteria from pine rhizosphere (13). Babich and Stotzky studied the effects of zinc on soil-borne bacteria and reported that $2 \mathrm{mmol}$ of zinc reduces the activity of bacteria (14). Cevik and Karaca reported that bacteria in pot soil are sensitive to $50 \mathrm{mg} / \mathrm{kg}$ zinc (15). In the present study, we determined a threshold value of $20 \mathrm{ppm}$ for soil $\mathrm{Zn}$ to allow different strains of $A$. chroococcum to survive, while concentrations more than $20 \mathrm{ppm}$ resulted in a linear reduction of growth, with a complete inhibition of growth at $50 \mathrm{ppm}$.

In a study by Shakibaei et al., bacteria were sensitive to $\mathrm{Zn}$ at $30 \mathrm{ppm}$ (16), a finding that is in line with our results. Malakootian and Toolabi studied the sensitivity of waste water-borne bacteria to $\mathrm{ZnO}$ nanoparticles and showed that the bacteria were not sensitive to an $80 \mathrm{ppm}$ concentration, while 100 and 1000 ppm concentrations resulted in $36 \%$ and $84 \%$ bacterial death, respectively (17). Our results are not in line with those of the latter study, and the difference could be due to the difference in the sampling locations as well as type of the microorganisms sampled and type of Zn metal used. Rajapaksha et al. have also shown that an increasing concentration of $\mathrm{Zn}$ for a short period of time linearly reduces the population size of soil-borne bacteria (18).

Our PCR results revealed the presence of nifH gene in all $12 \mathrm{~A}$. chroococcum strains $(6,19,20)$. The nifH gene product serves as a component of the nitrogenase system and has a role in the formation of Fe-protein complex. It is therefore, safe to assume that the presence of nifH gene is an indicator of the existence of the nitrogenase system and the ability to fix molecular nitrogen (10).

In conclusion, the results of the present study demonstrated that of the 12 isolated A. chroococcum strains, all were sensitive to a $50 \mathrm{ppm}$ concentration of zinc, and that the optimum concentration of zinc for the growth of these bacteria is $20 \mathrm{ppm}$. According to our results, it appears that the optimal activity and growth of the isolated A. chroococcum strains are in the presence of a 6-20 ppm zinc concentration. All these strains carried nifH gene, which is an indicator of the nitrogenase enzyme system, and nitrogen fixing capability.

\section{Acknowledgements}

There is no Acknowledgements.

\section{Authors' Contribution}

None declared.

\section{Financial Disclosure}

There is no Financial disclosure.

\section{Funding/Support}

There is no Funding/Support.

\section{References}

1. Canli M, Atli G. The relationships between heavy metal (Cd, Cr, $\mathrm{Cu}, \mathrm{Fe}, \mathrm{Pb}, \mathrm{Zn}$ ) levels and the size of six Mediterranean fish species. Environ Pollut. 2003;121(1):129-36.

2. Chen X, Hu S, Shen C, Dou C, Shi J, Chen Y. Interaction of Pseudomonas putida CZ1 with clays and ability of the composite to immobilize copper and zinc from solution. Bioresour Technol. 2009;100(1):330-7.

3. Bruins MR, Kapil S, Oehme FW. Microbial resistance to metals in the environment. Ecotoxicol Environ Saf. 2000;45(3):198-207.

4. Ashraf R, Ali TA. Effect of heavy metals on soil microbial community and mung beans seed germination. Pakistan $J$ Bot. 2007;39(2):629.

5. Nies DH. Microbial heavy-metal resistance.Appl Microbiol Biotech nol.1999;51(6):730-50.

6. Tejera N, Lluch C, Martìnez-Toledo MV, Gonzàlez-López J. Isolation and characterization of Azotobacter and Azospirillum strains from the sugarcane rhizosphere. Plant Soil. 2005;270(1):223-32.

7. Martyniuk S, Martyniuk M. Occurrence of Azotobacter Spp. in Some Polish Soils. Polish J Environ Stud. 2003;12(3).

8. Eleiwa ME, Hamed ER, Shehata HS. Biofertilizers and/or some micronutrients role on wheat plants grown on newly reclaimed soil. African JEcol. 2012;50(4):464-75.

9. Franche C, Lindström K, Elmerich C. Nitrogen-fixing bacteria associated with leguminous and non-leguminous plants. Plant Soil. 2009;321(1-2):35-59. 
10. Reinhardt EL, Ramos PL, Manfio GP, Barbosa HR, Pavan C, Moreira-Filho CA. Molecular characterization of nitrogen-fixing bacteria isolated from brazilian agricultural plants at Sao Paulo state. Braz J Microbiol. 2008;39(3):414-22.

11. Barrett SJ, Sneath PH. A numerical phenotypic taxonomic study of the genus Neisseria. Microbiology. 1994;140 ( Pt 10):2867-91.

12. Williams ST, Sharpe ME, Holt JG. Bergey's Manual of Systematic Bacteriology.Baltimore, USA:Williams and Wilkins; 1984.

13. Lu CQ, Huang BL. Isolation and characterization of Azotobacteria from pine rhizosphere. Afr JMicrobiol Res. 2010;4(12):1299-306.

14. Babich H, Stotzky G. Heavy metal toxicity to microbe-mediated ecologic processes: a review and potential application to regulatory policies. Environ Res. 1985;36(1):111-37.

15. Cevik N, Karaca A. Effect of Cadmium, Zinc, Copper and Fluoranthene on Soil Bacteria. Ankara Dept Soil Sci. 2003;6:1-14.

16. Shakibaie M, Khosravan A, Frahmand A, Zare S. Application Of
Metal Resistant Bacteria By Mutational Enhancment Technique For Bioremediation Of Copper And zinc From Industrial Wastes. Iran JEnviron Health Sci Engin. 2008;5(4):251-6.

17. Malakootian M, Toolabi A. Determining and Comparing the Effect of Nanoparticle $\mathrm{CuO}, \mathrm{TiO} 2$ and $\mathrm{ZnO}$ in Removing Gram Positive and Negative Bacteria from Wastewater Iran.J Yazd Univ Health. 2011;29(3):1-11.

18. Rajapaksha RM, Tobor-Kaplon MA, Baath E. Metal toxicity affects fungal and bacterial activities in soil differently. Appl Environ Microbiol. 2004;70(5):2966-73.

19. Ueda T, Suga Y, Yahiro N, Matsuguchi T. Remarkable N2-fixing bacterial diversity detected in rice roots by molecular evolutionary analysis of nifH gene sequences. J Bacteriol.1995;177(5):1414-7.

20. Khider AK, Khidher AM. Chromosomal nif Genes Transfer by Conjugation in Nitrogen Fixing Azotobacter chroococcum to Lactobacillus planetarium. Cur Res J Biol Sci. 2011;3(2):155-64. 